\title{
EFEKTIVITAS MEDIA PEMBELAJARAN BERBASIS COOPERATIVE LEARNING UNTUK MATA PELAJARAN IPA SD
}

\author{
Novi Larasati', Julaga Situmorang ${ }^{2}$, Hamonangan Tambunan ${ }^{3}$ \\ Sekolah Dasar Negeri 101784 Mabar $^{1}$, Universitas Negeri Medan ${ }^{2,3}$ \\ Novilarasati87@gmail.com ${ }^{1}$
}

\begin{abstract}
Abstrak: Penelitian ini bertujuan untuk: (1) menghasilkan media pembelajaran interaktif yang layak digunakan, mudah dipelajari dan dapat dipakai untuk pembelajaran individual, (2) untuk mengetahui keefektifan media pembelajaran interaktif yang dikembangkan untuk pembelajaran IPA pada siswa sekolah dasar. Jenis penelitian ini adalah penelitian pengembangan yang menggunakan model pengembangan produk Borg dan Gall yang dipadu dengan model pengembangan pembelajaran Dick dan Carey. Hasil penelitian menunjukkan: (1) uji ahli materi IPA berada pada kualifikasi sangat sesuai (95,08\%), (2) uji ahli desain pembelajaran berada pada kualifikasi sangat sesuai (93,96\%), (3) uji ahli rekayasa perangkat lunak dan desain grafis berada pada kualifikasi sangat sesuai (86,70\%), uji coba perorangan berada pada kualifikasi sangat sesuai (91,43 \%), uji coba kelompok kecil berada pada kualifikasi sangat sesuai (93,63 $\%)$, uji coba lapangan berada pada kualifikasi sangat sesuai (97.96\%). Dengan demikian, pengujian hipotesis membuktikan bahwa terdapat perbedaan yang signifikan antara hasil belajar siswa yang dibelajarkan dengan menggunakan media pembelajaran interaktif dan hasil belajar siswa yang dibelajarkan dengan menggunakan media pembelajaran poster.
\end{abstract}

Kata Kunci: Pengembangan media pebelajaran berbasis cooperative learning, hasil belajar IPA

\begin{abstract}
This study aims to : (1) generate an interactive learning proper use, easy to learn, and can be used for individual learning. (2) to determine the effectiveness of interactive learning media developed for Sains in primary school students. This type of research is the development of research that uses models Borg and Gall product development combined with the learning development model Dick and Carey. The results showed: (1) The saint's test materials experts are at a very appropriate qualification (95.08\%), (2) test the instructional design experts are at a very appropriate qualification (93.96\%), (3) test software engineering expert software and graphic design are at a very appropriate qualification (86.70\%), individual testing is at a very appropriate qualification (91.43\%), small group trial is at a very appropriate qualification (93.63\%), field trials are at a very appropriate qualification (97.96\%). Thus, hypothesis testing proves that there are significant differences between student learning outcomes that learned using interactive instructional media and student learning outcomes that learned by using learning media posters.
\end{abstract}

Keywords: Development of media based on cooperative learning, learning outcomes sains

\section{PENDAHULUAN}

Pendidikan mempunyai peran yang sangat strategis dalam meningkatkan kualitas sumber daya manusia dan upaya mewujudkan cita-cita bangsa Indonesia dalam mewujudkan kesejahteraan umum dan mencerdaskan kehidpan bangsa. Pemerintah merumuskan dalam Undang-undang Republik Indonesia No. 20 tahun 2003 tentang Sistem Pendidikan Nasional yang menjelaskan bahwa pendidikan dilakukan agar mendapat tujuan yang diharapkan bersama. Didalam tujuan pendidikan nasional menurut UU No. 20 tahun 2003 tentang Sistem Pendidikan Nasional menyatakan: "Pendidkan Nasional berfungsi mengembangkan kemampuan dan membentuk watak serta peradapan bangsa yang bermartabat dalam rangka mencerdaskan kehidupan bangsa.
Bertujuan untuk berkembangnya potensi didik agar menjadi manusia yamg beriman dan bertaqwa kepada Tuhan Yang Maha Esa, berakhlak mulia, sehat, berilmu, cakap, kreatif, mandiri dan menjadi warga Negara yang Demokratis serta bertanggung jawab".

Tujuan mata pelajaran Ilmu Pengetahuan Alam dalam Kurikulum Tingkat Satuan Pendidikan (2006:13) agar siswa memiliki kemampuan sebagai berikut : a) memperoleh keyakinan terhadap kebesaran Tuhan Yang Maha Esa berdasarkan keberadaan, keindahan dan keteraturan alam ciptaan-Nya, b) mengembangakan pengetahuan dan konsepkonsep IPA yang bermanfaat dan dapat diterapkan dalam kehidupan sehari-hari, c) mengembangkan rasa ingin tahu, sikap positif, dan kesadaran tentang adanya hubungan yang 
saling mempengaruhi antara IPA, lingkungan, teknologi dan masyarakat, d) mengembangkan keterampilan proses untuk menyelidiki alam sekitar, memecahkan masalah dan membuat keputusan, e) meningkatkan kesadaran untuk berperanserta dalam memelihara, menjaga dan melestarikan lingkungan alam.

Model pembelajaran IPA yang cocok untuk anak-anak sekolah dasar Indonesia adalah belajar melalui pengalaman langsung (learning doing). Model belajar ini memperkuat daya ingat anak dan biayanya sangat murah sebab menggunakan alat-alat dan media belajar yang ada dilingkungan anak sendiri.

Elliot dkk. (2014) menyatakan bahwa alat multimedia meningkatkan motivasi peserta didik dalam proses pembelajaran sains. Selanjutnya, hasil studi review baru-baru ini yang dilakukan oleh Moos dan Marroquin (2010) menunjukkan bahwa berbagai jenis CAI, seperti multimedia, hypermedia dan hypertext, mempengaruhi konstruksi motivasi berbasis teori, seperti tujuan penguasaan, sasaran kinerja, minat individu, minat situasional, motivasi intrinsik, motivasi ekstrinsik dan selfefficacy.

Multimedia interaktif merupakan media yang dapat digunakan dalam mendukung proses pembelajaran. Hal ini dilandasi oleh persepsi bahwa pembelajaran akan berlangsung dengan baik, efektif, dan menyenangkan jika didukung oleh media pembelajaran yang dapat menarik minat dan perhatian siswa serta dapat mengakomodasi berbagai gaya belajar siswa serta mampu menyediakan lingkungan belajar yang adaptif dan variatif. Siswa juga dapat mengontrol atau menentukan urutan materi pembelajaran yang sesuai dengan keinginan atau kebutuhan siswa itu sendiri.

Pengembangan media pembelajaran ini menggunakan model pengembangan Dick \& Carrey, tahapan pengembangannya antara lain melalui beberapa langkah yaitu: (a) mengidentifikasi media pembelajaran yang sesuai dengan peserta didik serta menyesuaikan dengan standar kompetensi yang ingin dicapai, (b) menganalisis pembelajaran, (c) mengidentifikasi karakteristik dan perilaku awal peserta didik, (d) merumuskan kompetensi dasar dan indikatornya, (e) menulis tes acuan patokan, (f) mengembangan strategi pembelajaran. Melalui langkah - langkah tersebut menjadikan peneliti dapat mengembangkan media pembelajaran yang sesuai dengan kebutuhan peserta didik di sekolah. Pengembangan media pembelajaran tersebut dapat berlangsung secara optimal harusnya didukung dengan fasilitas sarana dan prasarana yang baik juga dari sekolah tersebut.

Berdasarkan hasil observasi terbatas yang dilakukan peneliti pada saat kegiatan pembelajaran di SD Negeri 101784 Mabar tahun ajaran 2016-2017 kepada guru kelas V terlihat masih menggunakan media pembelajaran konvensional yaitu dengan papan tulis, LCD, whiteboard, grafis dan buku teks. Penggunaan multimedia interaktif berbasis TIK (Teknologi Informasi dan Komunikasi) pada pelajaran IPA di SD Negeri 101784 Mabar, khususnya menggunaan Macromedia Flash belum banyak ditemukan dalam proses pendidikan khususnya dalam pembelajaran IPA. Hal ini diduga sebagai salah satu penyebab rendahnya kualitas proses dan hasil pembelajaran IPA. Oleh sebab itu pengembangan multimedia interaktif adalah suatu upaya untuk memperbaiki proses dan hasil belajar.

Meningat berbagai keterbatasan yang dimiliki oleh peneliti maka pengembangan media pembelajaran berbasis cooperative learning dibatasi pada :1) Media pembelajaran berbasis cooperative learning yang akan dikembangkan pada kelas V SD, dan 2) Materi IPA yang akan dikembangkan dalam media interaktif ini adalah Alat Pernapasan Manusia dan Alat Pernapasan Hewan.

Digunakannya aplikasi Macromedia Flash disebabkan peneliti melihat realita dilapangan bahwa sebagian para pendidik sering menggunakan dan merancang media pembelajaran menggunakan aplikasi tersebut karena dianggap lebih familiar dan dikalangan siswa SD aplikasi ini juga dianggap lebih mudah menjalankannya, namun dalam penggunaannya para pendidik tidak menggunakan fasilitas yang terdapat pada aplikasi tersebut secara optimal. Dikalangan para pengembang media pembelajaran interaktif sendiri sering mengembangkan media pembelajaran yang aplikasi masih dianggap asing, seperti aplikasi Macromedia dreamweaver 8, $M X$, Adobe $C S$ dan sebagainya. Padahal media yang dikembangkan dapat dilakukan di aplikasi Macromedia Flash disamping itu siswa juga familiar terhadap aplikasi tersebut program ini juga mudah untuk dijalankan. 
Alasan utama mengapa Flash dipilih sebagai authoring tool pada pengembangan media pembelajaran interaktif ini dibanding tool-tool yang lain adalah animasi Flash ini berbasis vektor. Ini menguntungkan karena objek vektor dapat diperbesar dan tetap cantik sempurna tidak pecah, juga cepat downloadnya. Animasi Flash mempunyai ukuran file yang jauh lebih kecil dan bersifat streaming. Artinya, begitu sekian byte data awal file telah didownload, animasi dapat langsung dijalankan. Karena ukuran file (.swf)nya yang kecil maka ini akan menguntungkan apabila produk penelitian ini kedepan akan di up-load atau ditaruh di dalam web site sekolah sebagai e-learning.

Model pembelajaran Cooperative Learning merupakan salah satu model pembelajaran yang mendukung pembelajaran kontekstual. Sistem pengajaran Cooperative Learning dapat didefinisikan sebagai sistem kerja/ belajar kelompok yang terstruktur. Menurut Johnson (1993) yang termasuk di dalam struktur ini adalah lima unsur pokok, yaitu saling ketergantungan positif, tanggung jawab individual, interaksi personal, keahlian bekerja sama, dan proses kelompok.

Pembelajaran kooperatif adalah salah satu bentuk pembelajaran yang berdasarkan faham konstruktivis. Pembelajaran kooperatif merupakan strategi belajar dengan sejumlah siswa sebagai anggota kelompok kecil yang tingkat kemampuannya berbeda. Dalam menyelesaikan tugas kelompoknya, setiap siswa anggota kelompok harus saling bekerja sama dan saling membantu untuk memahami materi pelajaran. Dalam pembelajaran kooperatif, belajar dikatakan belum selesai jika salah satu teman dalam kelompok belum menguasai bahan pelajaran.

Media pembelajaran berbasis kooperatif pada pelajaran IPA di SD banyak menyajikan keadaan di lingkungan sekitar sekolah dan rumah peserta didik. Dimana dengan mengamati alam sekiitarnya peserta didik dapat langsung belajar. Alam sekitar dan penggunaan media interaktif dapat membantu siswa dalam belajar dengan tampilan yang berbeda. Animasi - animasi yang menarik sesuai dengan dunia anak SD dapat memotivasi peserta didik untuk berminat dan termotivasi untuk belajar.

Dengan melibatkan siswa secara aktif pada proses pembelajaran di dalam kelas, diharapkan siswa dapat lebih ikut bertanggung jawab terhadap peningkatan kemampuan belajarnya sendiri. Proses pembelajaran pun akan menjadi lebih menarik dan tidak membosankan sehingga diharapkan hasil belajar juga akan meningkat.

Pembelajaran IPA dapat dilakukan tanpa ada guru yang mendampingi peserta didik di dalam kelas. Peserta didik dapat belajar secara mandiri dengan bentuk kelompok - kelompok yang telah disusun sebelum pembelajaran tersebut berlangsung di dalam kelas.

Pembelajaran yang melibatkan siswa secara aktif dalam kelompok secara bergotong royong (kooperatif) akan menimbulkan suasana belajar paisipatif dan menjadi lebih hidup. Teknik pembelajaran Cooperative Learning dapat mendorong timbulnya gagasan yang lebih bermutu dan dapat meningkatkan kreativitas peserta didik dalam belajar.

Penggunaan multimedia dalam pembelajaran dapat memberikan manfaat yang besar bagi guru dan siswa. Manfaat yang dapat diperoleh adalah proses pembelajaran lebih menarik, lebih interaktif, jumlah waktu mengajar dapat dikurangi, kualitas belajar siswa dapat ditingkatkan dan proses belajar mengajar dapat dilakukan di mana dan kapan saja, serta sikap belajar siswa dapat ditingkatkan. Perencanaan multimedia pembelajaran interaktif ini mengacu pada model pengembangan Borg \& Gall (2005). Perencanaan multimedia pembelajaran interaktif ini berada dalam kawasan pengembangan. Menurut Seels \& Richey (1994) kawasan pengembangan berakar pada produksi media.

Kondisi ini disesuaikan dengan karakteristik anak pada kelas V SD yang berusia kira-kira 10 tahun yaitu :(1) senang bermain; (2) ingin tahu semuanya; (3) senang dan berminat pada pelajaran-pelajaran tertentu saja; (4) mengejar nilai yang tinggi saja yang dianggap bagus di sekolah; dan (5) anak-anak suka membentuk kelompok dengan teman sebayanya.

Desain pembelajaran berbasis komputer adalah storyboard, desain navigasi, desain grafis yang di dalamnya terdapat elemenelemen seperti: layout, warna, teks, animasi, video, dan audio. Dengan pemilihan yang tepat dalam mendesain multimedia pembelajaran diharapkan dapat meningkatkan motivasi dan belajar siswa. 
Borg dan Gall (2005: 775) mengajukan serangkaian tahap yang harus ditempuh dalam pendekatan ini mencakup 10 langkah umum, dijelaskan sebagaimana tahap-tahap berikut ini:

1) Research and information collecting; studi literatur yang berkaitan dengan permasalahan yang dikaji, dan persiapan untuk merumuskan kerangka kerja penelitian. Serta meminta pendapat para ahli bidang studi untuk menentukan apakah materi pembelajaran sudah tersedia.

2) Planning; merumuskan kecakapan dan keahlian yang berkaitan dengan permasalahan, menentukan tujuan yang akan dicapai pada setiap tahapan, dan jika mungkin/diperlukan melaksanakan studi kelayakan secara terbatas.

3) Develop preliminary form of product; mengembangkan bentuk permulaan dari produk yang akan dihasilkan, persiapan komponen pendukung, menyiapkan pedoman dan buku petunjuk, dan melakukan evaluasi terhadap kelayakan alat-alat pendukung. Uji kelayakan I (validasi) atas media pembelajaran tersebut dilakukan oleh ahli desain pembelajaran, ahli media pembelajaran dan ahli materi pelajaran yang telah berkompeten di bidangnya.

4) Preliminary field testing; melakukan ujicoba lapangan awal dalam skala terbatas dengan melibatkan subjek sebanyak 3 subjek (uji perseorangan) selanjutnya 9 subjek (uji kelompok kecil). Pada langkah ini pengumpulan dan analisis data dapat dilakukan dengan cara wawancara, observasi atau angket.

5) Main product revision; melakukan perbaikan terhadap produk awal yang dihasilkan berdasarkan hasil ujicoba awal. Perbaikan ini sangat mungkin dilakukan lebih dari satu kali, sesuai dengan hasil yang ditunjukkan dalam ujicoba terbatas, sehingga diperoleh draft produk (model) utama yang siap diujicoba lebih luas. Pada tahapan ini uji kelayakan II menjadi cikal bakal pengembangan media pembelajaran yang telah efektif digunakan oleh siswa.

6) Main field testing; uji coba utama yang melibatkan seluruh siswa yaitu \pm 30 subjek (kelompok besar)

7) Operational product revision; melakukan perbaikan/penyempurnaan terhadap hasil uji coba lebih luas, sehingga produk yang dikembangkan sudah merupakan desain model operasional yang siap divalidasi.

8) Operational field testing; uji validasi (kelayakan III) terhadap model operasional yang telah dihasilkan.

9) Final product revision; melakukan perbaikan akhir terhadap model yang dikembangkan guna menghasilkan produk akhir (final).

10) Dissemination and implementation; menyebarluaskan produk/model yang dikembangkan.

Untuk menghasilkan produk media pembelajaran interaktif diperlukan perencanaan, perancangan pembelajran yang baik. Dalam pengembangan media pembelajaran interaktif ini digunakan rancangan pembelajaran model Dick \& Carey (2005:9), dimana pengembangan pembelajaran dapat dilakukan dengan menggunakan tahap-tahap sebagai berikut:

1) Identifikasi tujuan pembelajaran; yakni menentukan tujuan dari sistem yang dibangun. Yang dimaksud dengan tujuan di sini adalah kemampuan yang dapat diperoleh pembelajar setelah menyelesaikan pelajaran.

2) Melakukan analisis pembelajaran; yakni menentukan kemampuan apa saja yang terlibat dalam proses pembelajaran untuk mencapai tujuan dan menganalisa topik atau materi yang akan dipelajari. Analisis ini akan menghasilkan diagram tentang keterampilan-keterampilan/ konsep dan menunjukkan keterkaitan antara keterampilan konsep tersebut.

3) Identifikasi perilaku dan karakteristik awal; yakni menentukan kemampuan minimum apa saja yang harus dimiliki pembelajar untuk menyelesaikan tugastugas. Ketika melakukan analisis terhadap keterampilan-keterampilan yang perlu dilatihkan dan tahapan prosedur yang perlu dilewati, juga harus dipertimbangkan keterampilan apa yang telah dimiliki siswa saat mulai mengikuti pengajaran. Yang penting juga untuk diidentifikasi adalah karakteristik khusus siswa yang mungkin ada hubungannya dengan rancangan aktivitas-aktivitas pengajaran. Misalnya pembelajar harus memliki kemampuan membaca, kemampuan perhitungan dasar atau kemampuan verbal dan spatial. Kepribadian dari pembelajar juga mempengaruhi design yang akan dibuat. 
4) Menulis tujuan kerja; yang bertujuan untuk menguraikan tujuan umum menjadi tujuan yang lebih spesifik pada tiap tahapan pembelajaran. Di tiap tahapan akan ada panduan pembelajaran dan pengukuran performansi pembelajar.

5) Mengembangkan tes acuan patokan; yakni merancang item tes untuk menyediakan kesempatan bagi pembelajar untuk mendemonstrasikan kemampuan dan pengetahuan yang dinyatakan dalam tujuan.

6) Mengembangkan strategi pembelajaran; yakni menentukan aktifitas instruksional yang membantu dalam pencapaian tujuan. Dimana, strategi tersebut akan meliputi aktivitas preinstruksional, penyampaian informasi, praktek dan balikan, testing, yang dilakukan lewat aktivitas. Misalnya membaca, mendengarkan, hingga eksplorasi internet. Aktifitas instruksional ini dapat dikembangkan oleh instruktur sesuai dengan latar belakang, kebutuhan, dan kemampuan pembelajar atau bisa saja pembelajar menggabungkan pengetahuan yang baru didapatkan dengan pengetahuan dan kemampuan yang telah dimiliki untuk membentuk pemahaman baru. Proses pembelajaran juga dapat dilakukan secara berkelompok atau individual.

7) Mengembangkan dan memilih materi pembelajaran; di mana berkaitan dengan media yang digunakan untuk proses pembelajaran untuk menghasilkan pengajaran yang meliputi petunjuk untuk siswa, bahan pelajaran, tes dan panduan guru. Media pembelajaran dapat berupa pemberian materi/perkuliahan, pemberian tugas, powerpoint, internet, paket computer-assisted-instruction, dan sebagainya. Permasalahan terletak pada penentuan media yang tepat untuk mencapai tujuan dan hal ini tidak sama untuk setiap pembelajar.

8) Mendesain dan melaksanakan evaluasi formatif; yang bertujuan menyediakan data untuk revisi dan pengembangan instructional materials. Selain itu, evaluasi ini juga dilakukan untuk mengumpulkan data yang akan digunakan untuk mengidentifikasi bagaimana meningkatkan pengajaran. Evaluasi ini dapat dilakukan, misalnya, dengan cara mewawancarai setiap pembelajar.
9) Merevisi kegiatan pembelajaran; merupakan bagian konstan dalam proses design. Revisi dilakukan berdasarkan hasil dari tiap komponen model ini. Pada tahap ini, data dari evaluasi sumatif yang telah dilakukan pada tahap sebelumnya diringkas dan dianalisis serta diinterpretasikan untuk diidentifikasi kesulitan yang dialami oleh siswa dalam mencapai tujuan pembelajaran. Begitu pula masukan dari hasil implementasi dari pakar/validator. Mungkin saja tahapantahapan pembelajaran kurang efektif dalam pencapaian tujuan akhir, atau aktifitas, media, dan penugasan yang telah ditentukan tidak membantu dalam memperoleh tujuan.

10) Mendesain dan melaksanakan evaluasi sumatif; yang bertujuan mempelajari efektifitas keseluruhan sistem dan dilakukan setelah tahap formative evaluation.

Pembelajaran kooperatif dibangun atas dasar teori konstruktivis sosial dari vygotsky dan teori perkembangan Vygotsky (zone of proximal development/ZPD) yang menyatakan bahwa pengetahuan dibangun melalui proses interaksi sosial, yaitu interaksi siswa dengan anggota komunitasnya yang lebih berkompeten. Interaksi sosial akan dapat menciptakan terjadinya pemrosan informasi pada individu siswa, sehingga siswa mampu melakukan dan menumbuhkan keinginan belajar, serta dapat berpengaruh positif terhadap motivasi dan hasil belajarnya. Penghargaan kelompok serta jadwal yang ketat memiliki struktur sangat penting untuk pembelajaran tim (Slavin, 1978; whicker, et. al 1997). Pembelajaran kooperatif, salah satu model pembelajaran berpusat pada siswa, telah didokumentasikan di seluruh literatur, efektif dalam membantu siswa memperoleh keterampilan praktis belajar, kemampuan komunikasi yang efektif dan kemampuan dalam hal pengetahuan pemahaman, dan mempromosikan sikap positif siswa terhadap pembelajaran mereka sendiri (Johnson \& Johnson, 2008; Slavin, 2011). Pembelajaran kooperatif juga berpengaruh pada penghargaan diri, perbaikan sikap terhadap mata pelajaran, teman sebaya, sekolah, serta gurunya, dan lebih terdorong untuk belajar dan berpikir (Lie, 2002). Dalam pembelajaran kooperatif, siswa belajar pada kelompok-kelompok kecil untuk 
mencapai tujuan yang sama dengan menggunakan keterampilan sosial.

Beberapa prinsip tentang pembelajaran kooperatif adalah: (1) Kelompok terdiri atas anggota yang heterogen (dalam kemampuan, jenis kelamin dan sebagainya); (2) Adanya penghargaan kelompok; (3) Adanya ketergantungan yang positif di antara anggota kelompok, karena setiap anggota kelompok bertanggung jawab atas keberhasilan melaksanakan tugas kelompok atau diberi tugas individual (tugas tidak selalu berupa tugas mengerjakan soal, dapat juga memahami materi pelajaran hingga dapat menjelaskan materi tersebut); (4) Guru mengamati kerja kelompok dan melakukan intervensi bila diperlukan; (5) Adanya tanggung jawab pribadi; (6) Setiap anggota kelompok harus siap menyajikan hasil kerja kelompok.

Media pembelajaran berbasis kooperatif pada pelajaran IPA di SD banyak menyajikan keadaan di lingkungan sekitar sekolah dan rumah peserta didik. Dimana dengan mengamati alam sekiitarnya peserta didik dapat langsung belajar. Alam sekitar dan penggunaan media interaktif dapat membantu siswa dalam belajar dengan tampilan yang berbeda. Animasi - animasi yang menarik sesuai dengan dunia anak SD dapat memotivasi peserta didik untuk berminat dan termotivasi untuk belajar.

Dengan melibatkan siswa secara aktif pada proses pembelajaran di dalam kelas, diharapkan siswa dapat lebih ikut bertanggung jawab terhadap peningkatan kemampuan belajarnya sendiri. Proses pembelajaran pun akan menjadi lebih menarik dan tidak membosankan sehingga diharapkan hasil belajar juga akan meningkat.

Media pembelajaran tersebut harus mampu menghadirkan beberapa bentuk materi pembelajaran seperti teks; gambar; animasi; suara; video; dan simulasi kejadian nyata dalam satu bentuk atau satu wadah program, agar lebih mudah digunakan dan membuat materi pembelajaran tersebut mudah dipahami.Media pembelajaran berbasis multimedia (menggunakan banyak media),dapat membantu siswa memahami materi pembelajaran dengan lebih mudah, menarik dan dapat membuat siswa merasakan kejadian nyata melalui simulasi.

Materi yang disajikan sesuai dengan tuntutan kurikulum dan berhubungan dengan kehidupan siswa sehari-hari baik di rumah maupun di sekolah ataupun di tempat-tempat lainnya. Seluruh materi yang ditampilkan, diaplikasikan dalam bentuk audio-visual yang didukung oleh fitur-fitur gambar animasi yang menarik dan tombol eksekusi, sehingga jika siswa mengklik kata-kata yang diinginkan akan terdengar pengucapannya dan terlihat penulisan katanya. Dengan cara ini, siswa akan lebih memahami makna dan penulisan dari kata-kata yang sedang dipelajarinya. Sementara itu, animasi dapat meningkatkan pembelajaran kosakata apabila digabungkan dengan narasi yang informatif dan menarik. Media ini dikemas dalam bentuk software dan disimpan di dalam sebuah CD ( Compact Disk), terasa ringan ketika dipegang, sehingga siswa dapat dengan mudah membawanya kemanapun dia pergi. Kondisi ini akan sangat sesuai dengan karakteristik anak usia SD, dimana keadaan tubuhnya belum kuat untuk membawa barang yang terlalu berat, selalu ingin tahu akan sesuatu, ingin belajar realistis, suka membentuk kelompok sebayanya, suka dengan permainan (game) dan selalu bergerak aktif. Simulasi dan visualisasi yang ditampilkan dalam multimedia interaktif kepada peserta didik akan dapat mengembangkan aspek kognitifnya, instruksi yang didengar dari media tersebut akan mempengaruhi kebiasaannya (aspek afektif) untuk selalu melakukannya berulang-ulang tanpa rasa takut salah dan malu, dan dilakukan selalu dengan menggunakan anggota tubuhnya(aspek psikomotorik).

Menurut Seels \& Richey (1994: 28-37) kawasan pengembangan berakar pada produksi media. Pengembangan adalah proses penterjemahan spesifikasi desain ke dalam bentuk fisik. Kawasan pengembangan mencakup banyak variasi teknologi yang digunakan dalam pembelajaran, tidak hanya terdiri atas perangkat keras pembelajaran tapi juga perangkat lunaknya, bahan-bahan audio visual, serta program atau paket yang merupakan paduan berbagai bagian. Di dalam kawasan pengembangan terdapat keterkaitan yang komplek antara teknologi dan teori yang mendukung baik desain, pesan, maupun strategi pembelajaran.

Berdasarkan pernyataan dari beberapa ahli media tersebut, maka dapat disimpulkan bahwa dengan penggunaan media dapat meningkatkan motivasi, rangsangan dan mempermudah siswa dalam memahami materi 
yang disampaikan dan dapat digunakan oleh guru sebagai alat bantu mengajar untuk meningkatkan kualitas siswa yang aktif dan interaktif sehingga dapat mendukung kelancaran kegiatan pembelajaran disekolah dalam mencapai tujuan pembelajaran.

\section{METODE}

Penelitian ini dilaksanakan di Sekolah Dasar Negeri 101784 Mabar Jalan Maangan 8 Mabar Hilir Kecamatan Labuhan Deli di wilayah Kabupaten Deli Serdang. Adapun langkah-langkah dalam penelitian ini menggunakan 2 tahap yakni tahap pertama adalah untuk pengembangan media dengan menghasilkan suatu produk dan tahap kedua adalah untuk mengetahui keefektifan produk.Untuk menghasilkan produk multimedia pembelajaran yang layak pakai dan sesuai dengan kebutuhan, maka perlu ditempuh suatu pendekatan penelitian.

Langkah - langkah pengembangan produk pembelajaran sebagai berikut:

1) Melakukan penelitian pendahuluan, yang meliputi: (a) identifikasi kebutuhan pembelajaran dan menentukan standar kompetensi mata pelajaran, (b) melakukan analisis pembelajaran, (c) mengidentifikasi karakteritikdan perilaku awal peserta didik, (d) menulis kompetensi dasar dan indikatornya, (e) menulis tes acuan patokan; menyusun strategi pembelajaran yang terdiri dari: penjelasan tentang tujuan instruksional, penjelasan relevansi isi pelajaran baru, penjelasan tentang materi pelajaran atau konsep, prinsip, dan prosedur yang akan dipelajari peserta didik, tes formatif dan umpan balik, dan tindak lanjut. (f) Mengembangkan bahan pembelajaran.

2) Pembuatan desain software, yang meliputi; (a) pembuatan naskah, (b) pembuatan storyboard, (c) Pembuatan Flow Chart View.

3) Pengumpulan bahan, yang meliputi; (a) Pembuatan dan pengumpulan gambar (image) dan animasi, (b) Perekaman dan pengumpulan audio

4) Mengembangkan dan membuat media pembelajaran

5) Review dan ujicoba produk.

6) Uji keefektifan produk

\section{Prosedur Penelitian}

Prosedur pengembangan yang dilakukan dalam penelitian pengembangan media pembelajaran multimedia interaktif ini guna memperoleh produk yang tepat guna maka dilakukan dalam lima tahapan, yakni: (1) tahapan melakukan penelitian pendahuluan, (2) tahap kedua pembuatan desain software, (3) tahap ketiga pengumpulan bahan, (4) tahap keempat membuat dan memproduksi multimedia interaktif, dan (5) tahap kelima yaitu review atau uji lapangan dalam rangka evaluasi formatif dan revisi produk.

Sasaran penelitian adalah pengembangan media pembelajaran multimedia interaktif pada mata pelajaran IPA. Pemilihan subjek penelitian ini berdasarkan pada kurangnya media pembelajaran multimedia pada mata pelajaran IPA di kelas V SD Negeri 101784 Mabar. Media yang dikembangkan tersebut berisi materi dan evaluasi yang disesuaikan dengan kebutuhan siswa dan kompetensi yang harus dikuasai siswa. Sedangkan sebagai subyek uji coba dalam penelitian dan pengembangan ini adalah siswa IV SD Negeri 101784 Mabar, yaitu dengan:

a) Validasi produk oleh pakar media dan materi pembelajaran

b) Uji Coba Perorangan/One-to-one evaluation oleh 3 siswa yang memiliki kemampuan rendah, sedang dan tinggi.

c) Uji Coba kelompok Kecil/Small group evaluation oleh 9 siswa.

d) Uji Coba lapangan/Field trial evaluaion berjumlah 30 siswa.

Titik awal penelitian ini diawali pada tahap II yaitu membuat desaian software. Hal itu disebabkan bahwa mengidentifikasi kebutuhan pembelajaran telah dilakukan sebelumnya, hal tersebut disebabkan bahwa media pembelajaran ini sebelumnya telah ada akan tetapi belum efektif penggunaannya. Maka daripada itulah peneliti mengembangkan kembali dengan mendesaian media pembelajaran yang lebih efektif daripada sebelumnya. Benang merah penelitian ini lebih difokuskan pada tahap II pada pengembangan media pembelajaran multimedia interaktif model Borg \& Gall (2005).

Uji coba produk awal dalam pengembangan ini dilaksanakan dengan melalui beberapa langkah sebagai berikut:

1) Langkah pertama menentukan sasaran uji coba yaitu ahli rancangan pembelajaran, 
ahli materi, ahli media, dan peserta didik. Masukan yang diharapkan dari para ahli masing-masing kesesuaian uraian materi dengan standar kompetensi dan kompetensi dasar, keakuratan materi, dan materi pendukung pembelajaran. Kemudian menganalisis konseptual serta revisi pengembangan tahap I.

2) Langkah kedua uji coba perorangan (uji satu-satu). Pada langkah ini produk telah diperbaiki pada revisi I (langkah I) dan angket penilaian diberikan pada pemakai secara perorangan dan yang tujuannya untuk mengetahui kesahihan produk setelah diperbaiki berdasarkan tinjauan yang terdiri dari 3 siswa. Masukan-masukan dari uji coba II ini selanjutnya dipakai sebagai dasar dalam melakukan perbaikan perbaikan terhadap produk (revisi II).

3) Langkah ketiga uji kelompok kecil. Uji coba ini dilakukan untuk mengetahui apakah masih terdapat kekurangankekurangan yang perlu diperbaiki dari produk yang dikembangkan setelah diskusi baik berdasarkan tinjauan ahli maupun pada uji coba perorangan. Jika masih terdapat kekurangannya maka berdasarkan masukan yang diperoleh akan dilakukan perbaikan III (revisi III).

4) Langkah keempat uji coba lapangan. Uji coba ini dilakukan untuk mengetahui apakah masih terdapat kekurangankekurangan yang perlu diperbaiki dari produk yang dikembangkan setelah diskusi baik berdasarkan tinjauan ahli maupun pada uji coba perorangan dan kelompok kecil. Jika masih terdapat kekurangannya maka berdasarkan masukan yang diperoleh akan dilakukan perbaikan IV (revisi IV). Jika tidak, maka produk dapat dinyatakan layak sebagai sumber belajar shahih di lapangan.

Teknik pengumpulan data yang dipergunakan dalam penelitian ini adalah sebagai berikut: (1) Angket, digunakan untuk menjaring data kebutuhan multimedia interaktif yang diberikan kepada guru dan siswa, untuk mengidentifikasi kebutuhan dan tujuan umum pembelajaran, untuk menjaring pendapat teknologi pendidikan, bidang studi, dan siswa, (2) Tes Hasil belajar, digunakan untuk mendapatkan data tentang perolehan hasil belajar siswa pada pembelajaran dan untuk mengetahui efektifitas multimedia interaktif pada pembelajaran yang dikembangkan, (3)
Observasi,digunakan untuk mengevaluasi kemampuan guru, kemampuan siswa, kondisi lingkungan saran dan prasarana yang ada serta data tentang kemungkinan siswa untuk mengikuti pembelajaran menggunakan multimedia interaktif dan evaluasi proses uji coba, (4) Dokumentasi, digunakan untuk melengkapi data hasil angket, observasi, dan wawancara juga digunakan untuk mengungkap ketersediaan bahan/dokumentasi yang ada.

\section{HASIL DAN PEMBAHASAN}

Hasil penelusuran dari angket yang disebar ditemukan bahwa $75 \%$ dari guru menyatakan membutuhkan media pembelajaran interaktif dalam proses pembelajaran agar proses pembelajaran berjalan lebih efektif, dan $100 \%$ siswa menyatakan membutuhkan sarana pembelajaran secara individual.

Tahapan uji coba produk dilakukan sebagai berikut: (1) validasi oleh ahli desain pembelajaran, (2) validasi oleh ahli materi IPA, (3) validasi oleh ahli rekayasa perangkat lunak, (4) melakukan analisis hasil validasi ahli materi dan ahli desain pembelajaran dan ahli rekayasa perangkat lunak dan desain grafis, (5) revisi I, (6) Evaluasi perorangan/satu-satu, (7) Analisis hasil evaluasi perorangan/satu-satu, (8) Revisi II, (9) Evaluasi kelompok kecil, (10) Analisis hasil evaluasi kelompok kecil, (11) Revisi III, (12) Uji coba lapangan, (13) Analisis hasil evaluasi uji coba lapangan, (14) Revisi IV, dan (15) Produk akhir. Produk akhir ini akan dilanjutkan dengan uji keefektifan produk.

Penilaian yang dilakukan oleh dua orang ahli materi meliputi aspek kualitas materi pembelajaran, kualitas strategi pembelajaran, dan sistem penyampaian pembelajaran pada media pembelajaran interaktif mata pelajaran IPA terdiri dari 2 topik, yaitu: (1) Alat Pernapasan Manusia, dan (2) Alat Pernapasan Hewan.

Ahli materi menilai media pembelajaran IPA berbasis multimedia interaktif berdasarkan tiga aspek yaitu kualitas materi pembelajaran, kualitas strategi pembelajaran dan kualitas sistem penyampaian pembelajaran yang menunjukkan persentase rata-rata penilaian masing-masing $96,25 \%$ pada aspek kualitas materi pembelajaran, 94,00\% pada aspek kualitas strategi pembelajaran, dan 95,00\% pada aspek sistem penyampaian pembelajaran termasuk kategori Sangat Sesuai secara keseluruhan, yang berarti media 
pembelajaran interaktif IPA berbasis cooperatif learning dapat memenuhi tuntutan kebutuhan pembelajaran.

Tabel 1 Persentase Rata-Rata Hasil Penilaian Terhadap Media Pembelajaran Interaktif IPA Berbasis Kooperatif Oleh Ahli Materi

\begin{tabular}{|c|c|c|c|}
\hline No. & Kategori & $\begin{array}{c}\text { Persentase } \\
\text { Rata-rata }\end{array}$ & Kriteria \\
\hline 1 & $\begin{array}{l}\text { Aspek materi } \\
\text { pembelajaran }\end{array}$ & $96,25 \%$ & $\begin{array}{c}\text { Sangat } \\
\text { Sesuai }\end{array}$ \\
\hline 2 & $\begin{array}{l}\text { Aspek } \\
\text { strategi } \\
\text { pembelajaran }\end{array}$ & $94,00 \%$ & $\begin{array}{c}\text { Sangat } \\
\text { Sesuai }\end{array}$ \\
\hline 3 & $\begin{array}{l}\text { Aspek sistem } \\
\text { penyampaian } \\
\text { pembelajaran }\end{array}$ & $95,00 \%$ & $\begin{array}{c}\text { Sangat } \\
\text { Sesuai }\end{array}$ \\
\hline & Rata-rata & $95,08 \%$ & $\begin{array}{l}\text { Sangat } \\
\text { Sesuai }\end{array}$ \\
\hline
\end{tabular}

Penilaian ahli desain pembelajaran terhadap aspek kualitas desain pembelajaran menunjukkan persentase rata-rata $95,00 \%$ termasuk kategori Sangat Sesuai yang berarti penampilan fisik media pembelajaran interaktif IPA berbasis cooperatif learning berfungsi dalam meningkatkan motivasi belajar peserta didik. Penilaian ahli desain pembelajaran terhadap aspek kualitas desain informasi menunjukkan persentase rata-rata $92,50 \%$ termasuk kategori Sangat Sesuai, yang berarti informasi media pembelajaran interaktif IPA berbasis cooperatif learning dapat memberikan kemudahan bagi siswa untuk memperoleh informasi yang diinginkan.

Penilaian ahli desain pembelajaran terhadap aspek kualitas desain interaksi menunjukkan persentase rata-rata 90,00\% termasuk kategori Sangat Sesuai yang berarti pengaturan isi pembelajaran memperhatikan aspek interaksi antara peserta siswa dengan pembelajaran sehingga dapat tercipta suatu kondisi yang mampu memfasilitasi belajar. Sedangkan persentase rata-rata pada aspek desain presentasi adalah 98,33 \% termasuk kategori Sangat Sesuai yang berarti presentasi dari media pembelajaran interaktif yang dikembangkan memiliki tampilan yang menarik sehingga mampu menimbulkan rasa ketertarikan siswa untuk melakukan pembelajaran.
Tabel 2 Persentase Rata-Rata Hasil Penilaian Terhadap Media Pembelajaran IPA Berbasis Kooperatif Oleh Ahli Desain Pembelajaran

\begin{tabular}{|c|l|c|l|}
\hline No. & Kategorisasi & $\begin{array}{c}\text { Persenta } \\
\text { se } \\
\text { Rata- } \\
\text { rata }\end{array}$ & Kriteria \\
\hline 1 & $\begin{array}{l}\text { Kualitas desain } \\
\text { pembelajaran }\end{array}$ & $95,00 \%$ & $\begin{array}{l}\text { Sangat } \\
\text { Sesuai }\end{array}$ \\
\hline 2 & $\begin{array}{l}\text { Kualitas desain } \\
\text { informasi }\end{array}$ & $92,50 \%$ & $\begin{array}{l}\text { Sangat } \\
\text { Sesuai }\end{array}$ \\
\hline 3 & $\begin{array}{l}\text { Kualitas desain } \\
\text { interaksi }\end{array}$ & $90,00 \%$ & $\begin{array}{l}\text { Sangat } \\
\text { Sesuai }\end{array}$ \\
\hline 4 & $\begin{array}{l}\text { Kualitas desain } \\
\text { presentasi }\end{array}$ & $98,33 \%$ & $\begin{array}{l}\text { Sangat } \\
\text { Sesuai }\end{array}$ \\
\hline & Rata-rata & $93,96 \%$ & $\begin{array}{l}\text { Sangat } \\
\text { Sesuai }\end{array}$ \\
\hline
\end{tabular}

Berdasarkan tanggapan ahli rekayasa perangkat lunak, dinyatakan bahwa media pembelajaran interaktif IPA berbasis cooperatif learning layak untuk uji coba lapangan dengan revisi sesuai saran yang dikemukakan, yaitu pada teks tombol navigasi jenis fontnya disesuaikan dengan karakter anak yang ceria.. Komentar-komentar ahli rekayasa perangkat lunak yang dirangkum menunjukkan kualitas pemrograman media pembelajaran menunjukkan skor rata-rata $86,25 \%$ termasuk kategori Sangat Sesuai, sementara untuk kualitas teknis atau tampilan menunjukkan skor rata-rata $87,14 \%$ termasuk kategori Sangat Sesuai yang berarti media pembelajaran interaktif IPA berbasis cooperatif learning dapat memberikan motivasi dan mampu menciptakan kondisi yang mampu memfasilitasi proses pembelajaran bagi siswa.

Tabel 3 Persentase Rata-Rata Hasil Penilain Terhadao Media Pembelajaran IPA Berbasis Kooperatif Oleh Perangkat Lunak Dan Grafis

\begin{tabular}{|c|l|c|c|}
\hline $\begin{array}{c}\text { No } \\
\cdot\end{array}$ & Kategorisasi & $\begin{array}{c}\text { Persenta } \\
\text { se Rata- } \\
\text { rata }\end{array}$ & Kriteria \\
\hline 1 & $\begin{array}{l}\text { Kualitas } \\
\text { Pemrograman }\end{array}$ & $86,25 \%$ & $\begin{array}{l}\text { Sangat } \\
\text { Sesuai }\end{array}$ \\
\hline 2 & $\begin{array}{l}\text { KualitasTekni } \\
\text { k atau } \\
\text { tampilan }\end{array}$ & $87,14 \%$ & $\begin{array}{l}\text { Sangat } \\
\text { Sesuai }\end{array}$ \\
\hline & Rata-rata & $86,70 \%$ & $\begin{array}{l}\text { Sangat } \\
\text { Sesuai }\end{array}$ \\
\hline
\end{tabular}


Persentase rata-rata hasil penilaian pada uji coba perorangan di SDN 101784 Mabar kelas V terhadap aspek kualitas materi pembelajaran sebesar 93,33\% dan aspek kualitas atau teknis tampilan sebesar $89,52 \%$ dan masing-masing termasuk kategori Sangat Sesuai. Berdasarkan hasil penilaian pada media pembelajaran interaktif IPA berbasis cooperatif learning pada uji coba perorangan tidak terdapat saran perbaikan.

Tabel 4 Persentase Rata-Rata Hasil Penilaian Terhadap Media IPA Berbasis Kooperatif Pada Uji Coba Perorangan

\begin{tabular}{|c|l|c|c|}
\hline No. & Kategorisasi & $\begin{array}{c}\text { Persentase } \\
\text { rata-rata }\end{array}$ & Kriteria \\
\hline 1 & $\begin{array}{l}\text { Aspek kualitas } \\
\text { materi } \\
\text { pembelajaran }\end{array}$ & $97,84 \%$ & $\begin{array}{c}\text { Sangat } \\
\text { Sesuai }\end{array}$ \\
\hline 2 & $\begin{array}{l}\text { Aspek kualitas } \\
\text { teknis/tampilan }\end{array}$ & $98,08 \%$ & $\begin{array}{l}\text { Sangat } \\
\text { Sesuai }\end{array}$ \\
\hline & Rata-rata & $97,96 \%$ & $\begin{array}{l}\text { Sangat } \\
\text { Sesuai }\end{array}$ \\
\hline
\end{tabular}

Persentase rata-rata dari hasil penelitian terhadap media pembelajaran interaktif berbasis cooperatif learning pada uji coba kelompok kecil di SDN 101784 Mabar kelas V terhadap aspek kualitas materi pembelajaran adalah sebesar 91,39\% dan aspek kualitas teknis atau tampilan sebesar $95,87 \%$ dan masing-masing termasuk kategori Sangat Sesuai.

Tabel 5 Persentase Rata-Rata Hasil Penilaian terhadap Media Pembelajaran Interaktif IPA Berbasis Kooperatif Pada Uji Coba Kelompok Kecil

\begin{tabular}{|c|l|c|c|}
\hline No. & Kategorisasi & $\begin{array}{c}\text { Persentase } \\
\text { rata-rata }\end{array}$ & Kriteria \\
\hline 1 & $\begin{array}{l}\text { Aspek kualitas } \\
\text { materi } \\
\text { pembelajaran }\end{array}$ & $91,39 \%$ & $\begin{array}{l}\text { Sangat } \\
\text { Sesuai }\end{array}$ \\
\hline 2 & $\begin{array}{l}\text { Aspek kualitas } \\
\text { teknis/tampilan }\end{array}$ & $95,87 \%$ & $\begin{array}{l}\text { Sangat } \\
\text { Sesuai }\end{array}$ \\
\hline & Rata-rata & $95,87 \%$ & $\begin{array}{l}\text { Sangat } \\
\text { Sesuai }\end{array}$ \\
\hline
\end{tabular}

Persentase rata-rata hasil penilaian terhadap media pembelajaran interaktif IPA berbasis cooperatif learning pada uji coba lapangan di SDN 101784 Mabar kelas V yaitu terhadap aspek kualitas materi pembelajaran sebesar 97,84\% dan aspek kualitas teknis/tampilan sebesar 98,08\% dan masingmasing termasuk kategori Sangat Sesuai.

Tabel 6 Persentase Rata-Rata Hasil Penilaian Terhadap Media Pembelajaran Interaktif IPA Berbasis Kooperatif Pada Uji Coba Lapangan

\begin{tabular}{|c|l|c|c|}
\hline No. & Kategorisasi & $\begin{array}{c}\text { Persentase } \\
\text { rata-rata }\end{array}$ & Kriteria \\
\hline 1 & $\begin{array}{l}\text { Aspek kualitas } \\
\text { materi } \\
\text { pembelajaran }\end{array}$ & $93,33 \%$ & $\begin{array}{l}\text { Sangat } \\
\text { Sesuai }\end{array}$ \\
\hline 2 & $\begin{array}{l}\text { Aspek kualitas } \\
\text { teknis/tampilan }\end{array}$ & $89,52 \%$ & $\begin{array}{l}\text { Sangat } \\
\text { Sesuai }\end{array}$ \\
\hline & Rata-rata & $\mathbf{9 1 , 4 3 \%}$ & $\begin{array}{l}\text { Sangat } \\
\text { Sesuai }\end{array}$ \\
\hline
\end{tabular}

Efektivitas produk pengembangan media pembelajran berbasis cooperative learning menggunakan uji normalitas yang dilakuan dengan melakukan sebaran skor variabel yang diteliti berasal dari populasi yang berdistribusi normal.

Tabel 7 Rangkuman Uji Normalitas dengan Uji Lilliefors

\begin{tabular}{|l|l|c|l|l|}
\hline No & \multicolumn{1}{|c|}{ Kelas } & $\mathrm{L}_{\text {hitung }}$ & $\mathrm{L}_{\text {tabel }}$ & Distribusi \\
\hline 1 & $\begin{array}{l}\text { Eksperim } \\
\text { en }\end{array}$ & 0,1221 & $\begin{array}{l}0,16 \\
1\end{array}$ & Normal \\
\hline 2 & Kontrol & 0,1574 & $\begin{array}{l}0,16 \\
1\end{array}$ & Normal \\
\hline
\end{tabular}

Berdasarkan uji normalitas kedua kelas di atas, maka dapat disimpulkan bahwa seluruh populasi data penelitian berdistribusi normal.

Perhitungan uji homogenitas untuk nilai hasil belajar diperoleh $\mathrm{F}_{\text {hitung }}=0,867$ sedangkan $F_{\text {tabel }}$ diperoleh sebesar 1,699 dengan $\alpha=0,05$. Sehingga diperoleh $\mathrm{F}_{\text {hitung }}<\mathrm{F}_{\text {tabel }}$ yaitu $0,86<$ 1,69, maka dapat disimpulkan bahwa data dari kedua sampel untuk hasil perlakuan mempunyai varians yang sama atau homogen

Tabel 8 Rangkuman Uji Homogenitas dengan Uji- t

\begin{tabular}{|l|l|c|c|c|}
\hline No & \multicolumn{1}{|c|}{ Kelas } & $\mathrm{F}_{\text {hitung }}$ & $\mathrm{F}_{\text {tabel }}$ & Varians \\
\hline 1 & $\begin{array}{l}\text { Eksperimen } \\
\text { Kontrol }\end{array}$ & 0,867 & 1,69 & $\begin{array}{c}\text { Homoge } \\
\mathrm{n}\end{array}$ \\
\hline
\end{tabular}

a. Hipotesis 1

Berdasarkan penilaian terhadap media pembelajaran interaktif IPA berbasis cooperatif learning pada uji coba lapangan dengan 60 siswa SDN 101784 Mabar untuk aspek kualitas materi pembelajaran dan aspek kualitas 
teknis/tampilan menunjukkan bahwa produk yang dikembangkan Sangat Sesuai atau layak digunakan.

\section{b. Hipotesis 2}

Maka selanjutnya untuk pengujian hipotesis 2 dapat menggunakan Uji t hasil test. Hal ini dilakukan untuk mengetahui apakah terdapat perbedaan kemampuan awal kelas kontrol dan kelas eksperimen dengan menggunakan uji t.

Menguji hipotesis dengan menggunakan uji-t

$$
\begin{gathered}
t_{\text {hitung }}=\frac{\overline{x 1}-\overline{x 2}}{S \sqrt{\frac{1}{n 1}}+\frac{1}{n 2}} \\
=\frac{22-\overline{21}}{17,08 \sqrt{\frac{1}{30}}+\frac{1}{30}} \\
=0,226
\end{gathered}
$$

dengan $\mathrm{S}^{2}=\frac{(n 1-n 2) s 1^{2}+(n 2-n 1) s 12^{2}}{n 1+n 2-2}=$ $\frac{(30-1) 14,57^{2}+(30-1) 19,28^{2}}{30+30-2}=17,08$

dengan $\mathrm{db}=\mathrm{n}_{1}+\mathrm{n}_{2}-2=30+30-2=58$

Berdasarkan hasil perhitungan yang diperoleh output $t_{\text {hitung }}$ sebesar 0,22 dan $t_{\text {tabel }}$ sebesar 1,67 pada taraf kepercayaan 95 persen. Maka diperoleh bahwa $t_{\text {hitung }}<\mathrm{t}_{\text {tabel }}$ atau 0,22 < 1,67 atau dengan kata lain Ha ditolak. Hal ini menunjukkan bahwa kemampuan awal siswa kelas kontrol dan kelas eksperimen adalah cenderung sama dan tidak berbeda secara signifikan. Hipotesis penelitian ini adalah sebagai berikut:

$\mathrm{Ha}$ : Media pembelajaran yang dikembangkan mampu meningkatkan hasil

\begin{tabular}{|c|c|}
\hline $\begin{array}{l}\text { : Media } \\
\text { dikembangkan } \\
\text { meningkatkan } \\
\text { hasil belajar II }\end{array}$ & $\begin{array}{c}\text { pembelajaran } \\
\text { tidak }\end{array}$ \\
\hline
\end{tabular}

Ho

$$
\text { belajar IPA }
$$

Dengan kata lain H0 ditolak dan Ha diterima, maka dapatlah disimpulkan bahwa hasil belajar IPA siswa yang menggunakan media pembelajaran multimedia interaktif lebih tinggi dari siswa yang diajar dengan menggunakan buku teks dengan efektifitas penggunaan media interaktif sebesar $72,22 \%$. Keefektifan media pembelajaran interaktif diperoleh dengan cara sebagai berikut:

$$
\begin{aligned}
X=\frac{\text { Jlh skor yang diperoleh }}{\text { Jlh Skor maksimal }} & \times 100 \% \\
= & \frac{650}{900} \times 100 \%=72,22 \%
\end{aligned}
$$

Nilai keefektifan media pembelajaran interaktif ini lebih tinggi dari nilai keefektifan pembelajaran tanpa media yaitu sebesar 71,33\% yang diuraikan sebagai berikut:

$$
\begin{aligned}
y=\frac{\text { Jlh skor yang diperoleh }}{\text { Jlh Skor maksimal }} & \times 100 \% \\
= & \frac{642}{900} \times 100 \%=71,33 \%
\end{aligned}
$$

\section{PEMBAHASAN}

Dari hasil pengolahan data penelitian yang dilakukan, terdapat perbedaan hasil belajar IPA antara siswa yang dibelajarkan dengan menggunakan media pembelajaran interaktif dan siswa yang dibelajarkan dengan tanpa media pembelajaran interaktif yaitu rata-rata hasil belajar IPA siswa yang dibelajarkan dengan menggunakan media pembelajaran interaktif lebih tinggi dibandingkan dengan siswa yang dibelajarkan tanpa menggunakan media pembelajaran interaktif. Maka, media yang telah dihasilkan adalah layak dan efektif untuk digunakan dalam pembelajaran.

Pengembangan media pembelajaran berbasis cooperative learning ini mengajarkan dan mendidik siswa untuk belajar mandiri dan bekerjasama dalam kelompok belajarnya. Guru memberikan arahan - arahan secara umum tentang suatu materi pelajaran. Siswa mengidentifikasi secara khusus materi tersebut sesuai dengan pikiran dan tanggapan siswa tersebut terhadap masalah yang terjadi di sekitarnya melalui mata pelajaran IPA. Lingkungan alam dapat dijadikan sebagai sumber belajar dengan cara dikemas dalam media animasi dan grafis yang memiliki warna yang cerah, gembira dan menyenangkan sesuai dengan dunia anak. Dengan tampilan media interaktif ini siswa akan termotivasi untuk belajar dan terjadi peningkatan hasil belajarnya.

Dengan menggunakan multimedia interaktif siswa dapat berinteraksi langsung dengan media sehingga proses pemahaman akan terjadi lebih cepat. Multimedia yang dikemas mengandung unsur pendidikan dan hiburan (edutainment) merupakan kemasan yang memberikan pengalaman belajar yang mengesankan bagi siswa. Media pembelajaran ini sangat praktis, karena media ini dapat dibawa oleh siswa dan dapat dipelajari dirumah karena media pembelajaran interaktif tersebut dalam bentuk CD (compact disk) yang ringan. Media pembelajaran ini juga dapat menguji kemampuan dan pemahaman siswa secara 
langsung melalui tes atau soal-soal latihan yang memiliki durasi waktu dan kunci jawaban yang benar, sehingga siswa dapat mengetahui kesalahan yang telah dilakukan dalam mengerjakan soal latihan tersebut. Media pembelajaran interaktif juga dilengkapi dengan rangkuman yang dapat membantu siswa memperoleh ringkasan materi pelajaran yang dipaparkan.

Efektivitas produk media interaktif ini telah diuji berdasarkan hasil belajar yang dicapai siswa dalam proses belajar dan mengajar yang dilakukan di 2 kelas yang berbeda. Diberi perlakuan yang berbeda yaitu menggunakan media interaktif dan tanpa media interaktif (media poster dan gambar). Secara uji homogenitas kedua kelas memiliki varaians yang sama atau homogen.

\section{PENUTUP}

Berdasarkan uji kelayakan produk dan hasil belajar media pembelajaran berbasis cooperative learning yang telah teruji pada siswa kelas V SDN 101784 Mabar, maka dapat disimpulkan sebagai berikut : (1) hasil validasi yang dilakukan oleh ahli materi pelajaran, ahli desain pembelajaran, dan ahli perangkat lunak / grafis menyatakan bahwa media pembelajaran ini layak untuk digunakan dalam pembelajaran, (2) hasil belajar siswa yang diajarkan dengan media pembelajaran berbasis cooperative learning lebih efektif.

\section{DAFTAR PUSTAKA}

Anita Lie. 2007. Cooperative Learning. Jakarta : Grasindo

Borg, W R \& Gall, M D. (2005). Educational research: an introduction, Fourth Edition. New York: Longman. Inc.

Dick, W. Carey dan Carey, L. 2005. The systematic design of instruction. United

States of America: Scott Foresman and Company.

Depdiknas. 2016. Kurikulum Tingkat Satuan Pengajaran. Jakarta : Depdiknas

Elliot D, Wilson D \& Boyle S 2014. Science learning via multimedia portal resources: The Scottish case. British Journal of Educational Technology, 45(4):571-580. doi: 10.1111/bjet.12085

Moos DC \& Marroquin E 2010. Multimedia, hypermedia, and hypertext: Motivation considered and reconsidered. Computers in Human Behavior, 26(3):265-276. doi: 10.1016/j.chb.2009.11.004

Seels, B.B. \& Richey, R.C. (1994). Instructional technology: the definition and domains of the field. (Terjemahan Yusuf Hadi Miarso, Dewi S Prawiradilaga \& Raphael Rahardjo. IPTPI, Unit Percetakan UNJ).

Slavin, Robert E. 2005. Cooperative Learning (cara efektif dan menyenangkan pacu prestasi seluruh peserta didik). Bandung: Nusa Media 